\title{
'The dead are just to drink from': recycling ideas of revenge among the western Dinka, South Sudan
}

\author{
Naomi R. Pendle
}

It was May 2012 and my journey to the dry season grazing lands (toc) in the flood plain of the western Dinka in northern South Sudan passed the homestead of Chief Madhol. ${ }^{1} \mathrm{He}$ was one of the longest-serving chiefs in Greater Gogrial. The Sudan People's Liberation Army's (SPLA's) control of the government of Southern Sudan since 2005 had brought sons of Greater Gogrial to the very heart of government leadership. Even President Salva Kiir himself was known to graze his cattle in the nearby toc. As I reached the chief's homestead, I stopped to greet him. As we sat and drank tea, Chief Madhol's son brought out his camera to show me photographs of men who had recently been killed. The photographs showed them lying where they had fallen in the toc. The vivid images of their violent deaths were now immortalized and propagated on the small screen of his digital camera. The chief's son, in his twenties, presented these to me as part of his explanation for the need for 'revenge' (guor). As we talked, the chief agreed with his son's demand for revenge but he was visibly disheartened by his inability to provide an adequate, peaceful alternative. For centuries, local authorities among the western Dinka have used cattle compensation $(p u k)$ as a socio-legal tool to peacefully satisfy people's spiritual and moral demands after being aggrieved by lethal violence against their family. In so doing, these authorities asserted their own normative authority over lethal violence and conduct in warfare. Yet, Chief Madhol claimed that compensation now lacked the necessary spiritual and legal significance. According to Madhol, the cattle of compensation have become of material benefit only for milk, making the dead nothing more than a vessel to drink from. Now, of the dead, people say: 'Ÿ̈n abï ruëth ajï̈p' / 'We will use them as a gourd of milk' (Chief Madhol).

For Chief Madhol and other western Dinka, the heart of the dilemma was whether puk could still recreate life after death. Puk could potentially do this by providing cattle for the marriage of a posthumous wife and legal children for the deceased (Deng 2010: 131; Lienhardt 1961: 25-6). Therefore, cattle could act as a substitute for a man (Lienhardt 1961: 25), and, as Hutchinson described in relation to a similar practice among the Nuer, cattle enabled the dead to have a second chance at 'life' (Hutchinson 1992). Such a reversal of death cools the demand for revenge from the deceased's family and the deceased's ghost, creating

\footnotetext{
Naomi R. Pendle is a post-doctoral researcher in the Centre for Public Authority and International Development (ESRC-funded grant ES/P008038/1) at the London School of Economics and Political Science. Her research focuses on public authority, prophecy, patterns of violence and local governance. Naomi has carried out ethnographic and qualitative research in South Sudan since 2009, with a particular focus on Nuer and Dinka communities. Email: N.R.Pendle@lse.ac.uk

${ }^{1}$ An alternative name has been used for this chief to preserve his anonymity.

(C) International African Institute 2018
} 
peace at the very epicentres of violence. ${ }^{2}$ A bäny bith (master of the fishing spear) would then have finally enacted the peace by hosting the peace-making sacrifice (Lienhardt 1961: 286-8). The feuding families would then claim a specific half of the sacrificed ox and each family would divide the animal between them based on their relationship to the deceased. When they ate their share of the meat, some people would even talk of eating the dead relative (Akec 2010: 180). ${ }^{3}$

Therefore, when the dead are eaten, peace is made. Yet, as Chief Madhol highlighted, by 2012, the dead were just to drink from. The cattle for compensation were inadequate to acquire a posthumous wife, to satisfy the demands for revenge, and for an ox to be slaughtered and shared to mark peace. Compensation no longer resulted in any peace making or eating, but only the immediate benefit of the cattle's milk.

The remaking of regimes of compensation and revenge has consequences for local feuding and lethal fights, but also for the national 'government wars' in South Sudan. Among the western Dinka, there are no necessary, clear boundaries between the social meanings of lethal violence in incidents of homicide and those of deaths during times of war. As discussed below, governments in South Sudan have long tried to draw a distinction between the moral consequences of lethal violence if the government carries out the violence (Hutchinson 1998). SPLA commanders drew on these idioms in the 1980s in attempts to make a division between the 'government wars' and the feuding between home communities (ibid.). Yet, if a division was ever established, recent years of warfare have erased any dividing line and have entwined patterns and idioms of feuding with the motives and modes of 'government wars'. Killing a man has long had consequences not just for the individuals involved but also for extended networks of the slayer and slain. These ideas have long been co-opted and manipulated by warring government elites. Therefore, regimes of revenge reshaped in local feuds have implications that reverberate in national conflicts and vice versa.

Since the early twentieth century, western Dinka regimes of compensation and revenge have been progressively secularized and bound up with government authority through the chiefs' courts. Regimes of revenge, compensation and lethal violence are not static but socio-legal processes entangled with relationships of power and legitimacy. Peace-making practices have been detached from their original meanings. In Africa, revenge and a lack of subsequent peace has often been a consequence of state government involvement interrupting previous cycles of lethal violence and peace making (Stewart and Strathern 2002). Therefore, revenge is often indicative not of the absence of government but of its presence. This tallies with a broader literature on public authorities in rural Africa that has noticed the presence of government power despite initial appearances that it is absent (Boone 2013; Leonardi 2013; Lund 2013).

This article explores how governments among the western Dinka since the early twentieth century have been progressively intrusive actors in the reshaping of these local, institutional, normative regimes of revenge and compensation, war and

\footnotetext{
${ }^{2}$ Nordstrom locates the beginning of peace at the epicentre of violence and notes the 'profound creativity average people employ in surviving war and forging peace' (Nordstrom 2004: 51).

${ }^{3}$ Not all families will immediately eat together after peace is made because of fears of deadly contamination (Howell 1951: 276).
} 
peace. Hutchinson documented similar changes among the Nuer (Hutchinson 1996). Governments have competed to capture control over revenge and compensation, diminishing the authority of religious leaders to govern these regimes. Governments have secularized and politicized the regimes of compensation and revenge. This has resulted in the stripping of divine sanctions behind these regimes and their replacement with the erratic will and capabilities of governments. Government involvement has brought these regimes closer to national politics and global flows of money. This has left the laws of compensation on shaky ground and has often meant that compensation is unable to appease the ongoing spiritual demands for revenge after someone's death.

\section{'Revenge' in conceptual debates}

Revenge is often portrayed as a phenomenon that explains conflict in itself (Migiro 2015). Revenge becomes about ancient rivalries (Kaldor 2013: 4), 'mindless' mass action (Richards 2005: 3), and a Hobbesian propensity to violence in the absence of the state. Outbursts of revenge in the post-Cold War era are explained by the lack of international intervention by superpower states (Kaplan 1994).

Admittedly, an account of 'revenge' must recognize the high passions involved (Stewart and Strathern 2002), and revenge can serve a psychological function (Keen 2007: 87). Western Dinka speak of the pain of the heart until revenge is achieved. As a man in his twenties described: 'If you see the killer of your brother, you feel as if you want to kill him.'

Yet, 'new barbarism' is an inadequate explanation of 'new wars' (Duffield 2000; Richards 2005: 9). 'Revenge' cannot simply be reduced to 'murder running rampant' (Boehm 1984: xi). Anthropologists, often with reference to studies of the Nuer and Dinka of Sudan, have long claimed that institutionalized revenge has regulatory functions that provide order in the absence of the state (Boehm 1984; Gluckman 1955). Feuds become evidence of moral order, not chaos (Boehm 1984: xii). In addition, peace apparently exists within the feud (Gluckman 1955), and the division between law, peace and feud is artificial (Caroll 2006). Recent interviews among the western Dinka echo this idea:

If you do not avenge the death of your relatives or anything bad done to you, it is a sign of weakness. Then anyone can challenge you anytime. By revenging, groups are kept in balance. Anyone tempted to do something bad will think of the reprisals they will face from the other side. In this way, antisocial acts are kept at bay because of this fear of revenge. $^{5}$

Commentators on South Sudan have argued that revenge provides order and protection because of the current absence of the state (Copnall 2014: 169; Hutton 2014: 18; Willems and Deng 2015: 7). However, Johnson argues that these ideas

\footnotetext{
${ }^{4}$ Interview with Dinka man in his twenties, Greater Rumbek Cattle Camp, May 2012 (in Dinka).

${ }^{5}$ Interview with educated Dinka elder, Lakes State, November 2014 (in English).
} 
of structural feuding misrepresent the historical record among the Nuer and Dinka and ignore the history of government power becoming entangled with these normative regimes (Johnson 1981). ${ }^{6}$

Alternatively, Stewart and Strathern claim that endless wars of feuding are a result of the presence, not absence, of the state. Feuding and revenge are in transformation through dialectic interaction with political circumstances. 'We are dealing with old ideas recycled through new political circumstances and themselves changing rapidly as a result, often becoming heightened rather than disappearing' (Stewart and Strathern 2002: 12). In contemporary contexts of the modern state, state structures interrupt the realization of earlier historical ritual processes that allowed violence to switch to peace making (Stewart and Strathern 2011; 2002: 13). 'It is, in effect, the result of the existence of state structures and the mutual impingement of local and national processes that feuding systems cannot realise their own larger cyclicities of violence and peace-making' (Stewart and Strathern 2002: 13). Once killings have escalated beyond a certain point, all controls are lost and compensation and reconciliation can no longer operate (ibid:: 13). Then, revenge appears to be endless.

Governments have long interfered with the process of revenge as they struggle to claim a monopoly on legitimate violence. Historians have documented how monarchs in Europe after the Middle Ages constructed the illegitimacy of 'revenge' and private violence in order to build their own authority (Caroll 2006). For a century, governments in South Sudan have also tried to construct their authority through their control of normative regimes of revenge and compensation, war and peace. Therefore, the regimes of 'revenge' are partly a product of governments. They are also a product of local responses to government.

\section{Are revenge and recent war in South Sudan inherently 'bad'?}

Since December 2013, the people of South Sudan have again been confronted with a national war that has added to the multiple government wars in the Sudans over the last century. Armed with increasingly elaborate weapons, contemporary armies have stripped people of their homes, livelihoods, livestock and lives. ${ }^{7}$ The international community, including the US, Europe and China, has been quick to dismiss recent violence as illegitimate. During the 1980s and 1990s, the SPLA waged a war against the government of Sudan. By the mid-1990s, this war neatly fitted into the new European and American meta-narrative against strong Islamic governments, with these Western governments seeing the SPLA's violence as justifiable to counter a strong, centralized, Islamic state (de Waal 2015; Woodward 2013). Yet, since 2011, South Sudan has been an independent country. In this context, European and American politicians have found the

\footnotetext{
${ }^{6}$ Thomas notes that, in the nineteenth century, foreign governments even used these ideas to justify slavery (Thomas 2015: 74).

${ }^{7}$ Within the first month of the violence, an estimated 10,000 people had been killed. In 2014, the International Crisis Group (ICG) suggested that at least 50,000 had been killed but criticized the UN for not counting (Martell 2014). Casie Copeland (Senior Analyst, ICG) argued, in that article, that the lack of record of the dead was dehumanizing the South Sudanese.
} 
contemporary violence inexplicable and inherently 'senseless', ${ }^{8}$ especially when the violence is explained in terms of revenge. For Western governments, the apparently private violence of revenge undermines their neoliberal ideas of the state's monopoly on violence. Until 2013, European and American governments supported a state-building agenda in South Sudan that hoped, in part, to counter the proliferation of revenge.

Therefore, the situation in South Sudan has become one in which Western governments try to set up in Africa 'a dichotomy between war as some kind of inherent "bad" (the world ruled by instincts and base desires), and peace as an ideal "good" (the world ruled by principle and law)' (Richards 2005: 3). In this situation, revenge becomes necessarily illegitimate. Wars in Africa have been described as disease-like and as a 'common threat' that needs to be countered through the imposition of a liberal peace (ibid.: 3 ).

South Sudanese who have again been trapped in this context of violence are also desperate for it to end. Yet, many South Sudanese have viewed aspects of the lethal violence as legitimate. International governments' perception of the inherent 'badness' of this non-state violence has not left room either to understand the violence or to differentiate between the just and unjust causes and conduct of the war. Instead, since the December 2013 outbreak of violence, international commentators have been eager to apportion culpability equally to both sides. By assuming that all non-government violence is wrong or 'criminal', there is less space for South Sudanese to protest against the violence of their government. There is also less space to comprehend how South Sudanese themselves understand, articulate and reshape the moral and legal boundaries of the violence they experience and execute.

War is best explained not in terms of momentary causes but instead in relation to evolving patterns of violence already embedded in society (Richards 2005: 11). The political economy and competition between elites in late 2013 undoubtedly helped cause the conflict that erupted (de Waal 2014; Johnson 2014). Yet, we also need to understand the impact of longer-term changes in regimes of lethal violence that allowed South Sudanese to perceive some of the post-December 2013 violence as legitimate. Institutional regimes of lethal violence, such as the laws governing compensation and revenge, play a part in these understandings. These ideas are contested and refashioned over time, in periods of war and peace, through violent conflict, but also through law and government. Western Dinka government elites are also entangled with regimes of revenge, not just through momentary discourse or fluid networks of patronage but also through the long-term reshaping of institutional regimes. Over time, the growing government sanction behind these regimes secularized compensation and made it vulnerable to the fluidity of government. As a result, western Dinka have found it increasingly problematic to find permanent and peaceful resolutions that satisfy spiritual obligations in cases of lethal violence through the payment of bloodwealth cattle compensation.

\footnotetext{
' 'Statement by the President on South Sudan', Office of the Press Secretary, The White House, 19 December $2013<$ http://www.whitehouse.gov/the-press-office/2013/12/19/statement-presidentsouth-sudan>, accessed 21 March 2015.
} 
As documented by Hutchinson, military leaders in South Sudan in the 1990s tried to draw a distinction between the moral and spiritual consequences of lethal killings during times of 'government wars'. In the 1980s, Dr Riek Machar (then a commander with the SPLA and now the former Vice President of South Sudan and leader of the armed opposition) argued that violent deaths during 'government wars' were devoid of the spiritual risks of pollution associated with acts of homicide and local feuding (Hutchinson 1996; 1998). This built on long-term attempts by governments in South Sudan to make government acts of lethal violence morally distinct (Hutchinson 1998). Dinka have also long drawn distinctions between different types of fighting and their scale, depending on whether sticks and clubs or spears were used (Howell 1951: 263). However, Dinka still faced the same spiritual consequences of lethal killing irrespective of the type of fighting. The distinction merely changed the likelihood of peaceful arbitration and reconciliation (ibid.: 263).

The western Dinka, like other South Sudanese, have never wholly accepted the government's clear distinction between the lethal violence of 'government wars' and the lethal violence of local feuding. Over the last decade, the character and ideologies of government have continued to change, and the government has employed powerful weapons in shocking levels of inter-communal and nationwide violence. This has further dissolved any dichotomy that had been drawn between 'government war' and 'local feud'. This has had tragic consequences for South Sudanese men, women and children.

As elsewhere, wartime elites use the discourse of revenge to mobilize immediate support (Kaldor 2013: 6). Lethal violence during times of war has also reshaped understandings of the consequences of death. For the western Dinka, there is no clear dichotomy between the moral boundaries of lethal violence in times of war and peace.

This article focuses on the western Dinka in Greater Gogrial. In recent decades, the western Dinka have been caught up in extended episodes of the civil wars fought between the government of Sudan, the SPLA and other armed South Sudanese groups. They have experienced first-hand the brute force of government and have been divided by competing political agendas. For example, Commander Kerubino Kuanyin Bol's defection from John Garang's SPLA in the early 1990s splintered communities and families. In recent politics, the lands of Gogrial have been the homelands of President Salva Kiir and many of his senior allies in the government and army of South Sudan.

The article is based on ethnographic research conducted among the western Dinka in Gogrial East between 2009 and 2013, as well as further research in South Sudan until early 2015. It looks at evolving ideas of revenge and compensation since the peace agreements signed around the turn of the millennium ended the wars of the 1980s and 1990s. The article is also informed by archival research in the South Sudan National Archive (Juba, South Sudan) and the Sudan Archive at Durham (UK).

Firstly, I discuss government capture of regimes of compensation and the subsequent secularization of these regimes. I also highlight how this has left revenge vulnerable to the changing politics and economic conditions of government. Therefore, the occurrence of revenge has often been as much a sign of government presence as of its absence. I then move on to discuss the consequences of this in the era since the end of the SPLA war with the government of Sudan. Secondly, I 
discuss how politicians have distorted the local cattle economy, resulting in bloodwealth being no longer sufficient to marry a valuable posthumous wife for the deceased. Thirdly, I argue that recurrent wars and government divisions have restricted the negotiating space within which local government Dinka chiefs can resolve local feuds and homicide cases peacefully and permanently.

\section{Government capture of compensation}

In 1922, the Anglo-Egyptian Condominium Government finally established a permanent administrative post in Gogrial after its defeat of the religious leader Ariathdit (Cormack 2014: 64-70). By this time, throughout the Sudan, the government was using a system of chiefs' courts (Johnson 1986; Howell 1951). The courts promoted the legal fiction that the substantive content of the law was based on previous customs, while the system merged pre-existing social norms with government laws and procedures (Leonardi et al. 2010: 19). ${ }^{9}$ The South Sudanese quickly started to use these courts regularly (ibid.).

Government officials incorporated compensation into the customary law as an alternative to revenge, and, therefore, entrenched compensation in law. The courts also established the norm that killing had collective consequences, as the government conceded that compensation be extracted collectively (Johnson 1986: 64). Government officials also tried to make intentional killing an act against the government itself. ${ }^{10}$ The chiefs' courts started imposing imprisonment and fines, as well as compensation. ${ }^{11}$ These government claims to control regimes of compensation and revenge challenged the powers of other public authorities.

Previously, bäny biths had presided over the exchange of compensation as a precondition to the peace-making sacrifice of an ox in order to end feuds and their spiritual consequences. Compensation was necessary as it provided cattle for the marriage of a posthumous wife for the deceased. Through the biological paternity of a close relative, the deceased could acquire legal children, who then carried his name into posterity (Deng 2010: 131; Lienhardt 1961: 25-6) and provided the whole lineage with restoration (Deng 1971; 2010; Madut 2013). If the deceased's brothers failed to fulfil their duty to acquire a posthumous wife for him, they risked the curse of the dead man (Deng 2010: 131). It is through this posterity that the deceased gained his immortality and challenged the consequences of death (Howell 1951). Therefore, cattle acted as a substitute for a man

\footnotetext{
${ }^{9}$ See, for example, a Dinka Ngok elder's discussion of whether $p u k$ should be paid even if the person injured fully recovers before later dying (Mijak 2002: 30).

${ }^{10}$ R. H. Owen, 'Letters Home', July 1927, in Sudan Archive, Durham, GB-0033-SAD 4/4/16; T. R. H. Wilson, 'Letter to My Dearest Mother', 18 March 1927, in Sudan Archive, Durham, GB-0033-SAD 4/4/18.

${ }^{11}$ District Commissioner of Western Nuer, 24 March 1937, Upper Nile Province 41.A.61, in South Sudan National Archive (Juba); 29 March 1938, Upper Nile Province 41.A.6, in South Sudan National Archive (Juba); 'Pro Forma of Culpable Homicide Cases' for period 1 January 1946 to 31 December 1946, Western Nuer District (WND), Upper Nile Province 41.A.6, in South Sudan National Archive (Juba); F. D. McJannet, 'Pro Forma of Culpable Homicide Cases' for period 1 January 1948 to 31 December 1948, WND, Upper Nile Province 41.A.6, in South Sudan National Archive (Juba).
} 
(Lienhardt 1961: 25), and, as among the Nuer, provided him with a second chance at 'life' (Hutchinson 1992). With this second chance, righteous anger was cooled and the bäny bith could oversee the peace ceremony.

The compensation cattle were not necessarily used for marriage immediately; there could be a delay so that the cattle could multiply before the negotiations (Howell 1951: 276). However, the relatives who received them were expected to contribute to the posthumous marriage (Deng 2010). Blood-wealth was paid even for those who already had children, as death still reduced procreative capacity (ibid.: 131). In the early twentieth century, those who were killed and already had children were often compensated with fewer cattle (Titherington 1927).

As well as the exchange of compensation, the end of the feud needed the bäny bith to oversee the sacrifice of a young ox (musr adosr or 'ox of peace', or musr de yuom or 'ox of splitting': literally, 'ox of the bone') in the presence of the warring families (Madut 2013: 83-4). The bäny bith would make invocations over the musr adsor before a member of each family threw the musr adsor to the floor and speared it to death. The animal would then be cut into equal halves and shared between the families. The entrails were thrown over the families. The bäny bith placed the spears in the ground among the remains of the entrails, and representatives of each family bit the spears. The bäny bith would end the ceremony by sprinkling ash on their knees. The splitting of the right leg of the muor adorr took place during this process (Lienhardt 1961: 287-8). Spiritual sanctions would be threatened against those who reopened the feud.

With the government incorporation of compensation into the customary law of the chiefs' courts, the government claimed for itself authority over compensation, feuding and peace making. However, compensation was not secularized immediately. In Gogrial, many of the first chiefs appointed by government were either close relatives of the bäny bith or were the bäny bith themselves (Cormack 2014: 70-5). For example, Giir Thiik, the first government-appointed paramount chief of the Apuk Dinka in eastern Gogrial, was the son of a bäny bith. As late as the 1940s, while Lienhardt was researching among the Dinka, despite over a decade of government involvement, a Dinka elder described compensation and the ability to reconcile as being under the authority of the ancestors (Lienhardt 1961: 286).

However, the government's creation of an association between the bäny bith and the government chiefs subordinated the spiritual powers of the bäny bith to the powers of government. Proximity to government also withered spiritual powers among the Nuer (Johnson 1997). When describing the situation among the Nuer, Johnson argues that there was 'a progressive secularisation of Nuer leadership and justice' that left 'a legal system very much dependent on government force as its main support' (Johnson 1986: 68).

Through the courts, governments sought to both restrict the legality of lethal, non-government violence and claim the government's power to kill with impunity (Hutchinson 1998). Refusal to accept compensation, and to instead seek revenge, became as illicit as the initial act of killing.

From the 1940s onwards, during a series of government-initiated chiefs' meetings, the government encouraged the standardization of western Dinka laws including compensation rates; these common laws and rates would become known as the Wanh-Alel. This initiative followed a conflict between people 
from Tonj and Rumbek. ${ }^{12}$ Western Dinka chiefs understand these laws of WanhAlel not only as a common code, but also as a governmental insistence on judicial redress as opposed to self-help justice. As one executive chief in Greater Gogrial explained:

If you give your cow to someone and he does not want to pay it back, then you go to toc and take another of his cows by force. Then that person will fight you. If you then go to court, you will pay a fine also. The fine will be because you went to take a cow by force. Instead, you should have first come to the court. Wanh-Alel says that the person who takes the cow by force causes conflict. ${ }^{13}$

Government officials denied that previous authorities (such as the bäny bith) had been capable of enforcing compensation. They claimed that previously people had only agreed to compensation because of expediency (Howell 1951: 275). Officials thought that religious leaders did not have executive authority (ibid.: 275) or that slave raids had disrupted their powers (Titherington 1927: 160). Officials claimed that the government allowed the evolution of Dinka law as it had created a new central authority capable of demanding compensation. ${ }^{14}$ This ignored the previously active role of religious leaders such as the bäny bith in enforcing puk between sections. ${ }^{15}$

At the same time, the government did not enforce the designation of musr adsor nor insist on a cow for the bäny bith's mediation services. The lack of a muər adorr detached compensation from the spiritual power that enforced reconciliation. Instead, the final cow of the thirty-one paid in compensation was now given to the government (Mijak 2002: 29). Additional cattle could also be demanded by the government as fines and fees. The government's taking of this payment reflected its assumed role as peacemaker.

Therefore, despite being legally bound to pay or accept compensation, a family might still not be willing to split the bone and seek reconciliation, which meant that compensation payments were no longer guaranteed to meet the spiritual demands needed for peace. Receipt of compensation often only delayed revenge for a generation; the children of the deceased (including those from a posthumous wife acquired with the compensation) would have the duty of revenge. This made matters even worse because children became reimagined as future avengers of their parents' deaths and were themselves legitimate targets of lethal violence.

In addition, compensation became reliant on the government's political will and capacity. As Nuer chiefs explained in relation to Nuer-Dinka border courts:

\footnotetext{
${ }^{12}$ Interview with Senior Dinka Chief and elders, Maper, June 2013 (in Dinka).

${ }^{13}$ Interview with Executive Chief, Greater Gogrial, July 2010 (in Dinka).

${ }^{14}$ Maine's nineteenth-century jurisprudence influenced policies in the empire in favour of the slow evolution of laws (Maine 1861). In Maitland's history of English law, it is argued that individual criminal culpability for homicide evolved as a replacement for revenge in more developed legal systems (Maitland 1895).

${ }^{15}$ Johnson gives the example of the Nuer prophet Ngundeng who forced compensation payments between groups in the Lou, and between the Lou and Gaajok (Johnson 1997: 105).
} 
When the government is together [not politically or militarily divided], then the chiefs of the Nuer and Dinka can talk and there can be compensation. Yet, the border chiefs can only meet in the context of Nuer-Dinka peace when there is government peace. ${ }^{16}$

At certain points, governments did promote Dinka-Dinka and Dinka-Nuer compensation and peace. By the 1940s in the western Dinka and Nuer, the Sudan government had formalized various cross-ethnic border courts and annual chiefs' meetings (Johnson 1986). ${ }^{17}$ Similar policies in Upper Nile allowed Nuer to start to speak of their relationship with the Dinka as only an intermittent 'ter' (feud) as opposed to a 'kor' (war) (Johnson 2003: 171). However, others in government had a growing concern that peace through government compensation did not end feuds. By the 1940s, there was Dinka frustration at the speed with which courts reached decisions, often long before people were willing to reconcile (Johnson 1986: 74).

The government asserted its own legitimacy to kill with impunity (Hutchinson 1998). As Hutchinson documents among the Nuer, this meant that Nuer government officials were to be devoid of the moral and spiritual consequences that usually resulted from Nuer-Nuer violence (ibid.). Dinka chiefs and government officials faced the same conundrum. However, the government's power to kill with impunity has never been accepted universally, and the government itself could be the legitimate target of revenge. In recent years, one Dinka elder explained that only if someone is killed by Nhialic (God), through lightning or illness, is there no obligation to demand revenge, because 'we don't know where Nhialic lives'.

\section{Government compensation after Sudan's independence}

After Sudan's independence in 1956, governments continued to demand an end to self-help justice and their authority to kill with impunity. In the 1960s, an armed Southern rebellion fought against the government in Khartoum, leaving the government with limited ability to enforce Nuer-Dinka compensation. It was only during the peace of the 1970s that there was the political will to re-establish compensation between these communities. ${ }^{18}$ This highlighted the vulnerability of the Nuer and Dinka to the inclinations and capacities of government.

In 1982, the Ananya II movement rebelled against the Sudan government, and, in 1983, the SPLA started its armed opposition. Southerners feared that Khartoum would neglect Southern voices, normative regimes and values, including by imposing sharia law at the cost of Southern customary laws. Southern intellectuals defended the value of the customary laws, visualizing customary laws as expressions of being South Sudanese. Makec and Deng have written accounts of

\footnotetext{
${ }^{16}$ Interview with chiefs of the Panyijar court, Ganyliel, October 2014 (in Nuer).

${ }^{17}$ Interview with man in his twenties, Greater Rumbek, May 2012 (in Dinka); interview with Town Chief, Panyijar, May 2012 (in Nuer).

${ }^{18}$ Speech given by Chief Rec Ater Bar in February 1999 at the 'Wunlit: Dinka-Nuer West Bank Peace and Reconciliation Conference'; transcript available online at the Sudan Open Archive: $<$ http://sudanarchive.net/cgi-bin/pagessoa? $=01$ off - vand-TX-wunlit+-100125- $\% 5$ bwunlit $+\% 5 \mathrm{~d}$ $\% 3 \mathrm{aTX}+-11-0-$ SectionLevel-0-0-1-1\&a=d\&cl=\&d=Dslpd174.1.26\&hl=1\&vpc=-1>, accessed March 2012.
} 
the customary laws to show their consistency with modern values (Deng 1971; Makec 1988).

As the SPLA gained more territorial control, it became a quasi-government in many Southern regions. Chiefs' courts in the western Dinka continued to settle cases of lethal killings in their jurisdictions by demanding compensation (Deng 2010: 137). Like previous governments, the SPLA claimed the right to use lethal violence with impunity (Hutchinson 1998); it also claimed moral authority over the boundaries of legitimate violence. Hutchinson has documented how Riek Machar - SPLA zonal commander of the western Nuer - spearheaded an ideological revolution that classified killings during the war as acts of government, detaching these killings from their usual spiritual dangers (ibid.).

The western Dinka were also confronted with the new scale of deaths brought about by the civil war. Families were left with inadequate cattle to provide wives for all those killed. In addition, there was no political space to hold courts or demand compensation. The increased use of guns for killing also prompted ambiguity about whether death by shooting had the same spiritual consequences (Hutchinson 1998: 63). Therefore, compensation no longer seemed possible and so did not have the power to combat death. Could compensation still be a guiding legal tool if its power was declining? However, western Dinka continued to hold firm to a belief in the spiritual consequences of lethal violence.

The Christian church in parts of Sudan has also challenged the meta-ethical foundations of compensation and revenge. However, the Catholic Church has been the dominant Christian influence on the western Dinka near Gogrial, and, in practice, it has been tolerant of continuing customs, minimizing its challenge to these norms. Fear of God and the spiritual consequences of fatal contamination that can arise after killing are still prevalent in the western Dinka (Mijak 2002: 55-6).

Since the 2005 comprehensive peace agreement (CPA) between the SPLA and the government of Sudan, people and courts in the western Dinka have actively tried to reassert the life-giving power of posthumous wives for the dead. For example, a woman's husband and five sons had all been killed during the SPLA wars, and so, in 2011, she had invested in a young wife to provide new sons for her deceased husband. When the new wife ran away with another male relative, the chiefs' court enforced the widow's legal rights to claim the wife's children as the legal children of her deceased husband.

\section{Compensation and revenge since 2005: elite interference with the cattle economy and Dinka-Dinka peace}

One significant change made by government officials to compensation since the 1930 s, as mentioned above, was the attempted standardization of payments imposed by the chiefs' courts (Leonardi et al. 2010). It was hoped that standardization would ease the exchange of compensation and promote the peaceful redress of grievances. Deng's and Makec's writings about these common Dinka laws in the 1970s and 1980s further entrenched the standardization of compensation.

The western Dinka had never agreed compensation based only on bride price: rates varied depending on the moral outrage caused by the killing. Accidental 
killings had long resulted in reduced compensation (Deng 1971; 2010: 132-5), and dheng piny (death after a surprise attack) had been contrasted with weec (which included negligent and accidental killing). However, government-imposed standard rates of compensation detached compensation rates from fluid bride prices completely (Howell 1951). Previously, the main purpose of $p u k$ had been as a bride price for a posthumous wife (ibid:: 275). Standard compensation rates disconnected compensation from the certainty that death would be challenged through marriage and posthumous procreation (Deng 1971; 2010). Over time, compensation rates were amended, but without reference to the fluidity of bride price.

Under the government, customary law differentiated compensation rates based on the form of homicide. For example, in the 1940s, government officials prescribed different rates for accidental killing and culpable homicide. ${ }^{19}$ In addition, blood-wealth also evolved over time: for example, among the Ngok Dinka, it increased from twenty cattle in the 1950s to thirty-one cattle by the 2000 s (Howell 1951; Mijak 2002). However, compensation rates did not vary with bride price: for example, in 1951, Howell noted that Ngok Dinka blood-wealth was fixed at twenty head of cattle while bridewealth had risen to about thirty cattle. At other times, blood-wealth exceeded bride price (Deng 2010: 153). Therefore, there was no longer certainty that compensation would satisfy spiritual demands following a killing.

In 1951, Howell posited that the disparity between bridewealth and bloodwealth might be overcome as the family of the deceased often kept the cattle for a few years before marriage so that the herd could multiply (Howell 1951: 276). However, since the wars of the 1980s, growing insecurity and conflict in the grazing lands has decreased the safety of herds, and thus any confidence that waiting will result in a larger herd.

In recent years, some Dinka chiefs have been proactive in their creative application of the law to ensure that compensation is capable of ending a feud, irrespective of government reshaping of compensation. For example, in 2012, a state governor created a special customary court headed by a western Dinka paramount chief to oversee cases after a series of lethal clan clashes. The court's mandate was limited to unintentional killings. If there had been intention, the court would have had to adhere to the governor's interpretation of the penal code and refer the cases to the statutory High Court. The High Court at the time favoured the death sentence over the payment of compensation. The paramount chief perceived that such a sentence would only add to the dead and create further demands for revenge, as opposed to offering a spiritual and moral solution. Therefore, the paramount chief employed a very narrow interpretation of 'intention'. If people gave a warning before they attacked - even if they shot and intended to kill during that attack - the chief interpreted this as a lack of intention to kill; the principal intention had been to raid cattle and not cause death. This allowed the chief to keep these cases in his court and demand compensation. The paramount chief thought this more likely to absolve the demand for revenge and keep the peace.

\footnotetext{
${ }^{19}$ J. M. Stubbs, 'Note on the customary laws of Aweil District Dinkas', 10 August 1945, in F. D. McJannet, 'Official Papers', in Sudan Archive at Durham, GB-0033-SAD 781/11/1-15.
} 
However, since 2005, elite interference with the cattle economy has made it increasingly difficult for even the most proactive Dinka chiefs to interpret the law in a way that makes compensation adequate. One of the most direct ways in which the Dinka experience the power of global money is through the restructuring of cattle ownership and the elite acquisition of large herds of cattle.

In 2005, the Sudan-SPLA civil war was formally ended through the CPA. This CPA also created the nascent government of South Sudan and funded it with half of Sudan's oil revenues. Politico-military elites circulated the majority of this revenue among themselves, creating a 'new aristocracy' that spent money on large houses and cars in Juba and internationally (de Waal 2014; Pinaud 2014). This opulent wealth was invisible to most South Sudanese who never travelled to Juba. ${ }^{20}$ Instead, the western Dinka most clearly saw the elite's oil wealth through their acquisition of thousands of cattle in their own grazing lands. Elites armed their kinsmen to defend their herds, while cattle herders believed that there was an implicit expectation on them to raid to ensure that each herd remained large. The elite leadership used these herds to build relationships, for patronage and to secure wealthy futures.

These shifts in the cattle economy have had an impact on the relevance of compensation. When compensation is owed from such large herds, for the kinsmen of the deceased the set rate of thirty-one cattle is minimal and meaningless; the loss of these cattle brings no real suffering to the kinsmen of the killer.

The elites' cattle wealth has also inflated bride price (Sommers and Schwartz 2011). Using their vast herds, the elite seek wives to reinforce their status in the community, extend their personal networks of socio-political power, and construct a legacy through which their name will survive their death. At the time of writing, cattle alone still legally confer paternity and are adequate for bride wealth among western Dinka. ${ }^{21}$ However, the inflation in bride price means that the static puk rates are now far below the contemporary bride price for a valuable wife. For example, in 2013, government leaders in Gogrial were paying bride price of as much as 400 cattle, while community members in the diaspora were paying with 200 cattle. It was routine for bride price to be between fifty and 100 cattle. Compensation for homicide at the time was just thirty-one cattle. Therefore, compensation cannot either resource a wife for the deceased or reduce the spiritual and social consequences of his death. As described in the introduction, this has reduced the cattle exchanged in compensation to nothing more than a material benefit for the milk they give. Therefore, the dead are just for their family to drink from, and compensation does not appease the need for revenge.

In 2013, after the death of his daughter, a chief described his ongoing demand for revenge:

\footnotetext{
${ }^{20}$ Occasionally, elites invested in construction projects in their homelands. For example, on the edge of Kuajok stands a large, elaborate hotel that has never been finished. These glimpses of wealth have prompted some local resentment, yet most local people lack any knowledge of the cost of such construction, which mitigates their frustration.

${ }^{21}$ The bride's family now sometimes also expects other gifts such as mattresses and umbrellas; however, the chiefs' courts near Gogrial have opted to uphold the necessity and sufficiency of cattle exchange.
} 
Compensation is not important now as it does not teach people a lesson. My own daughter was shot during a pupil demonstration. A soldier shot her. He was told to pay compensation, but I would prefer him to be killed. My daughter was educated and beautiful, and would get many cows for marriage. Now I am stranded as my daughter is not there. I have been given cows as compensation from the soldier, but they are so few. People will be finished soon. People will keep killing. Compensation means nothing now.

Since the CPA, politicians have also used the excuse of 'tradition' to demand contributions to compensation from poor kinsmen irrespective of their involvement in the violence, even if the killing occurred during ambitious and aggressive attempts by the more wealthy to expand their herds. This egalitarian obligation ignores disparities in wealth and responsibility for violence. Poorer kinsmen are often reluctant to pay for the spiritual consequences of the militarized actions of their elite relatives, while any hesitancy to pay can further agitate the family to whom the compensation is owed.

Elites have snubbed the spiritual and moral basis of compensation, and have taken advantage of its minimal, static rates under the law. As a result, bitter Dinka-Dinka feuds have arisen.

\section{Compensation and revenge since 2005: the lack of political space for Nuer-Dinka compensation}

In relation to Nuer-Dinka revenge, further obstacles have arisen to the restoration of peace through compensation. As discussed above, since the early twentieth century, governments have undercut the spiritual elements of homicide and blood-wealth, making compensation increasingly dependent on government will and sanction. During some periods, governments showed that their political will was in favour of compensation. However, over the last two decades, western Dinka have found it politically difficult to exchange compensation with certain groups, especially with the western Nuer.

In 1991, Riek Machar (from the western Nuer) defected from John Garang's SPLA. These warring commanders militarized ethnic relationships to mobilize support for their government wars (Jok and Hutchinson 1999; Hutchinson 2000). Commanders encouraged revenge against the ethnically identified 'other'. These politicians built on previous splits between areas controlled by the Bul Nuer and SPLA dating back to the early 1980s. The violence between the Nuer and the Dinka made their borderlands into a no-man's land and prevented peaceful meetings and inter-ethnic courts (Pendle 2017).

From 1997, the western Nuer erupted into an intra-Nuer civil war, following the military rivalry of Riek Machar and Paulino Matip (Johnson 2003). Western Nuer sought refuge among the western Dinka, creating a new appetite for Nuer-Dinka peace. The famous 1999 Wunlit peace meeting has become renowned as a local leaders' initiative (Bradbury et al. 2006; Santschi 2014). However, the meeting was not a court, ${ }^{22}$ and nor was it a time to revisit specific grievances nor exchange compensation. When, for example, Chief Rec Ater Biar suggested at the meeting

\footnotetext{
${ }^{22}$ Speech given by Awut Deng in February 1999 at the Wunlit conference, Sudan Open Archive.
} 
that cattle compensation be exchanged to uphold a 1978 peace agreement, his suggestion was dismissed. The large number of deaths made payment unrealistic. ${ }^{23} \mathrm{~A}$ white bull was sacrificed at the opening of Wunlit to symbolically cool hearts. ${ }^{24}$ However, no puk, not even of a symbolic nature, was exchanged.

As Wunlit excluded compensation, chiefs missed the opportunity to refashion compensation to tackle the new patterns of lethal violence. For example, new patterns of violence had included polarized ethnicities and had created new, larger political groupings. This gave rise to the question of whether a whole ethnic group was liable for compensation. And, if not, which part of the group was responsible? As Chief Gardial Abot Majak explained at Wunlit:

There was something that our brothers said yesterday that reminds me of the story about the bat and the birds. These creatures held a court case concerning a murder that had been committed by the birds. Together the birds decided to pay blood money. They called on the bat to contribute toward the compensation because, they said, he was one of them and therefore bears responsibility ...

As we were coming here several days ago a section of the Nuer attacked our area and raided cattle. This action, when we claim now that we are reconciling, are we actually including those sections that have attacked us so recently? We are all here today, all the way across, from west to east. Have you called on those Nuer raiders, as we have brought representatives of our people? Why is it that us Dinka have brought ourselves, but yet not all of your Nuer are represented here?25

Chief Gardial used the story of the birds and the bat to illustrate the ambiguity over who was responsible for the lethal violence of the 1990s, and who should now have the responsibility of paying blood-wealth. For this chief, the question related to the Nuer and whether they were collectively responsible and politically aligned.

There was also the question of the responsibility of military leaders to pay compensation. The chiefs who raised this at Wunlit touched on a much more politically sensitive question, implying that the SPLA was responsible for the killings. At the public Wunlit meeting, the dominant discourse was of Nuer-Dinka violence, with only occasionally people speaking out about the negative role of the SPLA and formal forces. ${ }^{26}$

Crucially, no compensation was exchanged at the Wunlit meeting. This lack of compensation meant that western Dinka found it increasingly impossible to imagine a future time when exchange of compensation with the Nuer would be possible. This growing impossibility of Nuer-Dinka exchange of compensation made it harder to imagine the end of revenge and violence.

\footnotetext{
${ }^{23}$ Interviews with male elder, Greater Rumbek, May 2012 (in Dinka); man in his twenties, Greater Rumbek, July 2012 (in Dinka).

${ }^{24}$ Speech given by Kuar Muon William Ray Kuong in February 1999 at the Wunlit conference, Sudan Open Archive.

${ }^{25}$ Speech given by Chief Gardial Abot Majak (Jur Maningar) in February 1999 at the Wunlit conference, Sudan Open Archive.

${ }^{26}$ The Wunlit peace meeting is often lauded for the chiefs' ability to express the elites' role in fuelling the violence. Much of this honest discussion took place before the formal public meeting itself. While some displeasure with the formal military forces was explicitly stated at Wunlit, some of these comments were also cut short.
} 
Nevertheless, the discussion at Wunlit recognized the need for a future legal space for exchange of compensation. ${ }^{27}$ Chiefs highlighted how, historically, compensation had been exchanged between Dinka and Nuer. As Chief Gaijal Dor explained:

Long ago when we were young men of Mayenethuc, and Awal Wol and Majak Ruai, and Mathil Anyuon, our land was united as one. If we quarrelled in the $t o c$, there was a severe punishment. If a Nuer were killed, 50 head of cattle were to be paid in compensation. This is known to Malwal Wun [a senior Nuer chief]. ${ }^{28}$

Yet, since Wunlit, the border courts between the western Dinka and Nuer have not been recreated as a regular judicial mechanism. Chiefs blame this on a lack of political will in Juba. Some chiefs have attempted to create ad hoc Nuer-Dinka courts. For example, in 2010, the western Nuer gave thirty-one cattle as compensation to the family of a Dinka fisherman. The fisherman was from Duk (to the east of the Nile) and the cattle travelled by boat. The family of the deceased and the chief of Duk had travelled to Ganyliel to threaten revenge if there was no compensation..$^{29}$ Yet, the national political allegiances between Duk Dinka and Nuer have been closer in recent years than those with Dinka to the west, and, therefore, there was more political space for compensation.

Other peace meetings since Wunlit have also failed to reinstate a relationship of compensation. The Anglo-Egyptian Condominium Government, in the early twentieth century, used local meetings, including inter-ethnic peace meetings, in order to enact local government and government justice, making these meetings the 'negotiation tables' of state-society relations (Leonardi 2015). Recent peace meetings have often happened on an ad hoc basis, at the whim of NGOs and government, and not on a regular, institutionalized basis. The absence of compensation in these meetings has forestalled any hope of justice and has made it harder to imagine peace.

Political leaders from the western Dinka and Nuer have been divided at the highest levels in the post-CPA government. As one Dinka chief described: 'There is no good government to make peace between us. ${ }^{30}$ Local leaders, including chiefs and spiritual leaders, feel that they have little space to act without higher-level government consent. 'People are afraid to call for an important elders' meeting because of fear of repression from the authorities. ${ }^{3} 1$

The unwillingness to restore non-violent justice and compensation is indicative of a lack of common government as experienced in the daily lives of South Sudanese since the CPA. While the government in Juba appeared to be unified until December 2013, local South Sudanese experienced its ongoing reluctance to reconstruct enduring inter-ethnic relations. 'The problem is from Juba. ${ }^{32}$

\footnotetext{
${ }^{27}$ Speech given by Chief Mabior Cuot in February 1999 at the Wunlit conference, Sudan Open Archive.

${ }^{28}$ Speech given by Chief Gaijal Dor in February 1999 at the Wunlit conference, Sudan Open Archive.

${ }^{29}$ Interview with Nuer chiefs, Ganyliel, October 2014 (in Nuer).

${ }^{30}$ Interview with Executive Chief, Greater Gogrial, July 2012 (in Dinka).

${ }^{31}$ Interview with Chief, Western Nuer, December 2014 (in Nuer).

${ }^{32}$ Interview with former Border Chief, Ganyliel, October 2014 (in Nuer).
} 
On 15 December 2013, fighting erupted in an SPLA barracks in Juba. The soldiers' lethal violence was enacted in the spatial and political heart of the South Sudan government. Yet, the South Sudanese knew that there was little hope of compensation or peaceful redress for the grievances that confronted them. Selfhelp justice through lethal, violent revenge was a remaining option. The demand for revenge shaped the violence of those in and out of uniform and echoed western Nuer and Dinka violence since the 2005 CPA.

Shifting patterns of revenge in the rural homes of the western Nuer and Dinka are directly linked to national conflicts. For example, during western Nuer-Dinka fighting in 1997, an old Dinka man was killed. His son was already in the army and progressing rapidly through the ranks. Nearly two decades later, the man's son played a senior role in coordinating the pro-government SPLA violence in Juba in December 2013 in which Nuer civilians were targeted (International Crisis Group 2014; Human Rights Watch 2014). In private, this senior government commander cited the raids that killed his father in 1997 and the need for revenge as a justification for the violence against the Nuer in Juba in 2013. ${ }^{33}$ Many of those who were involved in the violence in December 2013 that targeted the Nuer used this national, political conflict to further private demands for revenge. The political leadership also used narratives of revenge (African Union 2015: 239). There has been a 'politicization of private lives' but there is also a 'privatization of political violence' (Kalyvas 2006), as the South Sudanese take advantage of the national conflict for their own private wars. Therefore, the wars since December 2013 are not a disjuncture but a continuation of shifting patterns of violence.

However, some local leaders have taken risks to try to reclaim the power of compensation to forge peace. For example, in 2014, a group of men from the western Dinka were hunting near the western Nuer. A group of Nuer young men happened upon them, attacked them, and killed one of the group. Both groups then fled. At the time, this blurred border between the lands of the Nuer and Dinka was also the boundary between the SPLA-IO (SPLA In Opposition) and the Juba government in the ongoing South Sudanese civil war. There was no de facto common government between the groups of the killed and the killers. The warring parties did not insist on compensation; instead, they prohibited peace making.

In fact, the man who was killed had maternal family among the Nuer. His parents' marriage had occurred at a time of Nuer-Dinka peace and cooperation. Upon the son's death in 2014, his family did not want to end this relationship despite the macro politics and demands for division along Nuer-Dinka lines. Therefore, they opted to make the potentially hazardous journey to the Nuerlands to seek compensation and avoid revenge. The killer's family initially refused compensation, suggesting that the context of war ended any obligation, but still brought the case to a chiefs' court.

When the case reached the chiefs' courts, the SPLA-IO local government was informed. At the time, the SPLA-IO leadership was not willing to hold a court case with people from government-held areas. The local government leader made it clear that he did not want to be part of the case, nor would he let the SPLA-IO authorities rule on it. The chiefs interpreted this as permission to

\footnotetext{
${ }^{33}$ In public, no commander has admitted culpability or an ethnically driven motivation.
} 
hold the case out of sight of the local government, and moved the hearing to a secret location away from the usual court tree adjacent to the local government office. The chiefs' court found in favour of the family of the deceased and insisted that puk should be paid to the petitioning Dinka family. A relationship of compensation and reconciliation could be reconstructed irrespective of the wars of the government.

Despite no common government and the ongoing war, the family and chiefs reconstructed a relationship of peace. In doing this they took the risk of crossing front lines. The grieving family and chiefs used compensation to dilute people's everyday experience of government and its blunt, relentless violence. Therefore, compensation has the power to appease the moral and spiritual consequences of death even in opposition to the power of governments.

\section{Conclusion}

South Sudanese politico-military elites have spent decades cycling in and out of declarations of war and agreements of peace. Yet, much more serious for the people of South Sudan are the changing patterns of lethal violence that continue through times of national wars and peace, and that reshape the consequences of such violence. Among the western Dinka, the presence of revenge has not been indicative of the absence of government, but has instead been symptomatic of increasingly intrusive interference in regimes of lethal violence by centralized and militarized national governments.

This echoes findings by Stewart and Strathern (2002) that link revenge to the presence of government. Governments among the western Dinka over the last century have progressively had jurisdiction over regimes of compensation and revenge, reshaping the legal and normative boundaries that limit lethal killings. At times, governments have used compensation to bring peace. However, the secularization of compensation and government power behind the peace have left compensation subordinate to the will and capacity of government. Compensation no longer necessarily carries the guarantee that it will appease spiritual demands for revenge. This has meant that, in recent years, the politics around the oil wealth of government elites has seeped into Dinka-Dinka compensation, making its payment less valued. In addition, political divisions between government elites have eroded the government's inclination to permit Nuer-Dinka compensation and have closed the political space for its exchange. Western Dinka have retained a belief in the spiritual consequences of death; they continue to believe that the consequences of death can be challenged through posthumous marriage and legal children. Yet, government-backed compensation in the current political climate has failed to provide compensation that guarantees the fulfilment of these spiritual demands.

When compensation is delinked from reconciliation and the appeasement of revenge, at best it is delayed until the next generation. This can make matters even worse if this extension of the feud into the next generation results in children also being actors in the feud and, therefore, legitimate targets for killing. Since 2013, children have been intentionally killed and their bodies mutilated, including removing their genitals (African Union 2015). The dead are left without anyone to provide life after death. 
In light of these conclusions, as scholars continue to study the relationship between conflict, government and public authorities, it is essential that research does not merely focus on immediate acts of mobilization by government actors. Instead, there is a need for a much broader historical understanding of the ways in which governments and other public authorities have reshaped regimes of lethal violence in times of war and peace. Additionally, there is still a need to better understand the consequences of the secularization of compensation in contexts where lethal violence has maintained its spiritual consequences.

\section{Acknowledgements}

I am thankful for the detailed and useful feedback of the reviewers who have contributed to the shape and content of this article. I am grateful for the thoughtful, timely feedback of Cherry Leonardi (Durham) and her consistent, insightful encouragement. I am also grateful for Sharon Hutchinson's informal mentoring during previous work together. Jonathan continues to be an inspiration of a different kind. However, this article is really the product of the work, ideas and saddening struggles of my friends in the western Dinka. I am grateful that they gave me the time and had the patience to explain everything to me even though I often appeared to know less than a child.

\section{References}

African Union (2015) Final Report of the African Union Commission of Inquiry on South Sudan. Addis Ababa: African Union.

Akec, P. M. (2010) 'Interview' in F. Deng, Customary Law in the Modern World: the crossfire of Sudan's war of identities. Abingdon: Routledge.

Boehm, C. (1984) Blood Revenge: the enactment and management of conflict in Montenegro and other tribal societies. Pennsylvania PA: University of Pennsylvania Press.

Boone, C. (2013) 'Land regimes and the structure of politics: patterns of landrelated conflict', Africa 83 (1): 188-203.

Bradbury, M., J. Ryle, M. Medley and K. Sansculotte-Greenidge (2006) Local Peace Processes in Sudan: a baseline study. London: Rift Valley Institute.

Caroll, S. (2006) Blood and Violence in Early Modern France. Oxford: Oxford University Press.

Copnall, J. (2014) A Poisonous Thorn in Our Hearts: Sudan and South Sudan's bitter and incomplete divorce. London: Hurst and Company.

Cormack, Z. (2014) 'The making and remaking of Gogrial: landscape, history and memory in South Sudan'. PhD thesis, University of Durham.

Deng, F. M. (1971) Tradition and Modernization: a challenge for law among the Dinka of Sudan. New Haven CT: Yale University Press.

Deng, F. M. (2010) Customary Law in the Modern World: the crossfire of Sudan's war of identities. Abingdon: Routledge.

de Waal, A. (2014) 'When kleptocracy becomes insolvent: root causes of the civil war in South Sudan', African Affairs 113 (452): 347-69. 
de Waal, A. (2015) 'Sudan expert: international community enabled South Sudanese corruption', Al Jazeera, 12 April <http://america.aljazeera.com/ watch/shows/fault-lines/articles/2015/4/12/sudan-expert-international-community-enabled-south-sudanese-corruption.html>, accessed 1 May 2016.

Duffield, M. (2000) 'Globalization, transborder trade, and war economies' in D. Malone and M. R. Berdal (eds), Greed and Grievance: economic agendas in civil wars. Boulder CO: Lynne Rienner.

Gluckman, M. (1955) 'The peace in the feud', Past and Present 8 (1): 1-14.

Howell, P. P. (1951) 'Notes on the Ngork Dinka', Sudan Notes and Records 32: 239-93.

Human Rights Watch (2014) 'South Sudan's new war: abuses by government and opposition forces', Human Rights Watch, 7 August < https://www.hrw.org/report/ 2014/08/07/south-sudans-new-war/abuses-government-and-opposition-forces $>$, accessed 1 January 2015.

Hutchinson, S. (1992) 'The cattle of money and the cattle of girls among the Nuer, 1930-83', American Ethnologist 19 (2): 294-316.

Hutchinson, S. (1996) Nuer Dilemmas: coping with money, war, and the state. Berkeley CA: University of California Press.

Hutchinson, S. (1998) 'Death, memory and the politics of legitimation: Nuer experiences of the continuing second Sudanese civil war' in R. Werbner (ed.), Memory and the Postcolony: African anthropology and the critique of power. London: Zed Books.

Hutchinson, S. (2000) 'Nuer ethnicity militarized', Anthropology Today 16 (3): 6-13.

Hutton, L. (2014) South Sudan: fragility at independence to a crisis of sovereignty. The Hague: Clingendael.

International Crisis Group (2014) South Sudan: a civil war by any other name. Africa Report 217. Brussels: International Crisis Group.

Johnson, D. (1981) 'The fighting Nuer: primary sources and origins of a stereotype', Africa 51 (1): 508-27.

Johnson, D. (1986) 'Judicial regulation and administrative control: customary law and the Nuer, 1898-1954', Journal of African History 27 (1): 59-78.

Johnson, D. (1997) Nuer Prophets: a history of prophecy from the Upper Nile in the nineteenth and twentieth centuries. Oxford: Oxford University Press.

Johnson, D. (2003) The Root Causes of Sudan's Civil Wars. Woodbridge: James Currey.

Johnson, D. (2014) 'Briefing: the crisis in South Sudan', African Affairs 113 (451): 300-9.

Jok, J. and S. Hutchinson (1999) 'Sudan's prolonged second civil war and the militarization of Nuer and Dinka ethnic identities', African Studies Review 42 (2): $125-45$.

Kaldor, M. (2013) 'In defense of "new wars", Stability 2 (1): 1-16.

Kalyvas, S. (2006) The Logic of Violence in Civil Wars. Cambridge: Cambridge University Press.

Kaplan, R. D. (1994) 'The coming anarchy: how scarcity, crime, overpopulation, tribalism, and disease are rapidly destroying the social fabric of our planet', Atlantic Monthly 113 (273): 44-75.

Keen, D. (2007) Complex Emergencies. Cambridge: Polity Press. 
Leonardi, C. (2013) Dealing with Government in South Sudan: history of chiefship, community and state. Woodbridge: James Currey.

Leonardi, C. (2015) 'Points of order? Local government meetings as the negotiation table in South Sudanese history', Journal of Eastern African Studies 9 (4): 650-68.

Leonardi, C., L. N. Moro, M. Santschi and D. H. Isser (2010) Local Justice in Southern Sudan. London: Rift Valley Institute.

Lienhardt, G. (1961) Divinity and Experience: the religion of the Dinka. Oxford: Oxford University Press.

Lund, C. (2013) 'The past and space: on arguments in African land control', Africa 83 (1): 14-35.

Madut, L. A. (2013) Dinka Religion: their belief system. Juba: Universal Printers Company.

Maine, H. S. (1861) Ancient Law, its Connection with the Early History of Society, and its Relation to Modern Ideas. 1st edition. London: John Murray.

Maitland, F. W. (ed.) (1895) History of English Law before the Time of Edward I. Cambridge: Cambridge University Press.

Makec, J. W. (1988) Customary Law of the Dinka People of Sudan: in comparison with the aspects of Western and Islamic laws. London: Afroworld.

Martell, P. (2014) '50,000 and not counting: South Sudan's war dead' < http:/l reliefweb.int/report/south-sudan/50000-and-not-counting-south-sudans-wardead>, accessed 5 September 2015.

Migiro, K. (2015) 'Aid groups raise fears of escalating violence in South Sudan', Reuters, 21 May <http://www.reuters.com/article/us-southsudan-war/aid-groupsraise-fears-of-escalating-violence-in-south-sudan-idUSKBN0O626K20150521>, accessed 5 June 2015.

Mijak, D. B. (2002) The Traditional Systems of Justice and Peace in Abyei. Khartoum: UNDP Sudan $<$ http://sudanarchive.net/cgi-bin/pagessoa? $=01$ off vand-TX-puk-100125- $\% 5$ bpuk $\% 5 \mathrm{~d} \% 3 \mathrm{aTX}+-1-0-$ SectionLevel-0-0-1 puk-1\&a= $\mathrm{d} \& \mathrm{cl}=\& \mathrm{~d}=\mathrm{Dslpd} 8.1 .31>$, accessed November 2015 .

Nordstrom, C. (2004) Shadows of War: violence, power, and international profiteering in the twenty-first century. Berkeley CA: University of California Press.

Pendle, N. (2017) 'Contesting the militarization of the places where they met: the landscapes of the western Nuer and Dinka (South Sudan)', Journal of Eastern African Studies 11 (1): 64-85.

Pinaud, C. (2014) 'South Sudan: civil war, predation and the making of military aristocracy', African Affairs 113 (451): 192-221.

Richards, P. (ed.) (2005) No Peace, No War: an anthology of contemporary armed conflict. Oxford: James Currey.

Santschi, M. (2014) 'Traditional authorities, local justice and local conflict resolution mechanisms in South Sudan' in S. Hellmuller and M. Santschi (eds), Is Local Beautiful? Peacebuilding between international interventions and locally led initiatives. Cham: Springer.

Sommers, M. and S. Schwartz (2011) 'Dowry and division: youth and state building in South Sudan'. Special Report 295. Washington DC: United States Institute of Peace <http://www.usip.org/sites/default/files/SR_295.pdf>, accessed 1 November 2015.

Stewart, P. J. and A. J. Strathern (2002) Violence: theory and ethnography. London: Continuum. 
Stewart, P. J. and A. J. Strathern (2011) Peace-making and the Imagination: Papua New Guinea perspectives. Brisbane: University of Queensland Press.

Thomas, E. (2015) South Sudan: a slow liberation. London: Zed Books.

Titherington, G. W. (1927) 'The Riak Dinka of Bahe El Ghazal Province', Sudan Notes and Records 10: 159-209.

Willems, R. and D. Deng (2015) 'Justice and conflict in South Sudan: observations from a pilot study'. The Hague: University for Peace <http://www.cmi. no/file/3253-Justice-and-Conflict-in-South-Sudan-Pilot-Survey-BriefingPaper.pdf $>$, accessed 15 May 2016.

Woodward, P. (2013) US Foreign Policy and the Horn of Africa. Abingdon: Routledge.

\begin{abstract}
Governments in South Sudan have long built their authority on their ability to fashion changing regimes of revenge and compensation, war and peace. Governments' capture of these regimes has resulted in the secularization of compensation despite the ongoing spiritual consequences of lethal violence. This article explores these issues by focusing on the western Dinka of Greater Gogrial. In recent years, they have been closely linked to the highest levels of government through familial networks and comradeship. Violent revenge among the western Dinka is best understood not as revealing the absence of institutions of government, but as a consequence of the projection of government power over the details of local, normative codes and sanctions. In this age of post-state violence with automatic weapons, oil-wealthy elites and ambiguous rights, government authority and intention have often been erratic. As government authority now backs up these regimes of compensation and revenge, governments' shifting nature has reshaped their meaning. In the last decade, the declining political space for peace and the disruption of the cattle economy has undermined the current value of compensation and its ability to appease the spiritual and moral demands for revenge. It has even distorted regimes to the extent that children become legitimate targets for revenge. The article is informed by archival sources and based on ethnographic research among the western Dinka (South Sudan) between 2010 and 2013, and further research in South Sudan until 2015.
\end{abstract}

\title{
Résumé
}

Au Soudan du Sud, les gouvernements assoient depuis longtemps leur autorité sur leur capacité à façonner des régimes changeants de revanche et de compensation, de guerre et de paix. En s'emparant de ces régimes, les gouvernements ont entraîné la sécularisation de la compensation malgré les conséquences spirituelles continues de la violence meurtrière. Cet article explore ces questions en se concentrant sur les Dinka occidentaux du Greater Gogrial. Ces dernières années, ils sont étroitement liés aux plus niveaux de l'État à travers des réseaux familiaux et des liens de camaraderie. Le meilleur moyen de comprendre la violence des revanches chez les Dinka occidentaux est non pas comme révélatrice de l'absence d'organes gouvernementaux, mais comme une conséquence de la projection du pouvoir de l'État sur les détails des codes locaux et normatifs et des sanctions. En cette période de violence post-étatique caractérisée par des armes automatiques, des élites qui se sont enrichies avec le pétrole et des droits ambigus, l'autorité et 
l'intention du gouvernement ont souvent été inconstantes. L'autorité du gouvernement soutenant désormais ces régimes de compensation et de revanche, la nature changeante des gouvernements a refaçonné leur sens. Au cours des dix dernières années, le déclin de l'espace politique pour la paix et la perturbation de l'économie du bétail ont sapé la valeur actuelle de compensation et sa capacité à apaiser les demandes spirituelles et morales de revanche. Les régimes s'en trouvent déformés au point de faire des enfants des cibles de revanche légitimes. L'article s'appuie sur des sources archivistiques et sur des recherches ethnographiques menées auprès des Dinka occidentaux (Soudan du Sud) entre 2010 et 2013, et d'autres travaux de recherche effectués au Soudan du Sud jusqu'en 2015. 